\title{
A Comparison between the Environmental Impact of Each Batik Production Process
}

\author{
Etika Muslimah $^{1}$, Sudjito Soeparman ${ }^{2}$, Bagyo Yanuwiyadi ${ }^{3}$, Harsuko Riniwati ${ }^{4}$ \\ \{etika.muslimah@ums.ac.id ${ }^{1}$ \} \\ Universitas Brawijaya, Indonesia ${ }^{1,2,3,4}$ \\ Universitas Muhammadiyah Surakarta, Indonesia ${ }^{1}$
}

\begin{abstract}
Batik is a native Indonesian cultural heritage. The batik industry is spread in several cities such as Surakarta, Yogyakarta, Pekalongan, Cirebon, Madura and other cities. The development of the batik industry not only increased people incomes but also on various environmental impact. The batik production process consists of several stages, each stage using different chemicals, so the impact is also different. This study, therefore, aims to compare the environmental impacts caused by each stage in the batik production process, in an that it can be seen where the process with the highest environmental impact can be proposed for further improvement. The parameters analyzed include Human Health, Ecosystem Quality and Resources. The result is a coloring that has the greatest environmental impact when compared to other processes. This was due to the use of chemicals for the coloring process, encompassing remasol, water glass, soda ash mixed with water. The many chemicals used cause the greatest environmental impact compared to other processes. Therefore, reducing and reusing of chemicals dyes for the subsequent coloring processes or the adoption of natural dyes from plants origin are capable of reducing the environmental impacts.
\end{abstract}

Keywords: Environmental Impact, Process, Batik, Coloring, Chemicals.

\section{Introduction}

Small industries is an industry that employs a few people, characterized by the use of small capital and a very simple production process. They also do not use modern technology to increase production capacity. Furthermore, they do not have awareness on the importance of cleaner production systems. The production process which includes the processing of inputs to outputs using materials and energy are not environmentally friendly. Small industrial area that cares for the preservation of the environment and the efficient use of production factors is still unthinkable as industrial progress positively impacts on the Indonesian economy. On the other hand, the progress of the industry also had a negative impact, especially in the aspect of environmental sustainability. Pollutants of industrial products is a problem that causes environmental pollution [1]. Batik is one of the well-known featured products in Surakarta. Indonesian Batik is a cultural work that has been developed and preserved for many generations. The international community has recognized the existence of batik. Nowadays, batik has experienced rapid development over time, due to the contemporary growing consumer demand. There are variations of batik motif which have been developed from the traditional motif. Today the traditional motif has grown, batik motif blends with modern modifications and then the needs of people from all walks of life are met, making batik one of the mass industrial 
commodities [2]. The type produced batik include handwriting batik and stamp batik. In addition to these two products, there are also SMEs that produce fabrics jumputan, which is obtained through slightly different with batik processes. The technology in the production process is also very simple and characterized by small production capacity. In addition, batik is generated by SMEs in the form of handwriting and stamp batik. Now only a small part of batik production is using natural dyes, but most are using synthetic dyes.

The batik industry has grown rapidly; over the years, there are about 25 micro and small industry that produces batik. Their products are handwriting, stamp and print batik. These materials require synthetic dyes and natural dyes[3], hence the SMEs is conducted very simply, and the number of workers range from about 1-5 people, which include the owner sometimes. In addition, most SME do not pay attention to environmental sustainability. This can be seen from the activities carried out more likely to only pursue maximum profits without seeing the environmental impacts caused. This kind of thing also happens in other countries, in SMEs environment management practices are more focused on manufacturing activity rather than focus the company relating to the environment [4]. Inaddition, SMEsalsohavetechnicalconstraints in terms that SMEs have technical constraints in terms that they unskilled technical personnel in matters related to cleaner production systems, e.g., energy-efficient technology. Besides the lack of time and capital availability, it also changes other obstacles, where most SMEs are in a competitive market, there is not much time to consider about energy efficiency and cleaner production systems, they spend more time for marketing products, fulfilling orders, negotiate prices, and maintain delivery schedules[5]. Previous research explained that one of the obstacles faced by small industry when faced with environmental problems is the cost factor[6]. The investment cost to achieve green industry is considered unprofitable.

The phenomenon observed in the batik industry today is characterized by an environmental destruction, which result from the wastewater produced, and the amount of energy used as seen in Pekalongan batik industry. the process of batik production in some SMEs have problems in the production where the process separates the wax from the fabric using firewood, resulting in the emergence of water pollution. This is because the use of water in the washing process was greatly exaggerated by the need for a copious continuous flow, which impacts on the cost and the amount of liquid wasted. In addition to excessive water consumption, the dye used during the production of batik is majority chemical based, which have a negative impact on the environment / natural ecosystems. The generated liquid waste of the production process of batik is then filtered in Waste Water Treatment Plant (WWTP) and subsequently dumped into the river. However, this practice is not adopted by all SMEs dispose of liquid waste by filtration WWTP in advance, as some tend to directly discharged waste into the river, leading to the presence of wide range of chemicals affiliated with numerous damages to natural ecosystems. A study of the environmental impact is required to analyze the batik production process as well as the impact of inefficient raw materials use [7]. The situation in Surakarta, SMEs that has been integrated with WWTP not guaranteed to have clean production, this is because some of the remaining wastewater is discharged into the river. The WWTP channel only accepts coloring wastes that have high concentrations of chemicals (deep black and smelly) and the rest of the washing batik waste will still be discharged into river waterways [8]. A previous research recommends the resourceful use of raw materials in order to reduce the waste and environmental impact called eco-efficiency. Efficiency (saving) of raw materials can minimize the amount of waste and the environmental impact caused especially in the batik production value chain [9].

This study is, therefore, aimed at comparing the environmental impacts of by each stage in the batik production process. This consists of coloring, stamping, and the dye removal process, the first and second washing, as well as the second coloring, and the wax separation processes. 
In addition, the different uses of raw materials lead to variations in environmental impacts, and the knowledge of specific effects is the first step to sought for solutions, e.g., through the reduction or replacement of raw materials.

\section{Research Methods}

This research was analyzed using the Life Cycle Assessment (LCA) method, using SimaPro software and the data produced at each stage is needed. Raw materials are identified and Categorized According to the constituent ingredients.

Life Cycle Assessment (LCA) is a method adopted for this research. LCA is a quantitative method used to evaluate the impact of human activities on the environment. The tool is useful for providing information on the impact of products, processes, and measurement operations on the environment $[10]$.

Meanwhile, according to Life Cycle Assessment is a tool used to evaluate the impacts associated with all phases of the product life cycle cradle to grave both downstream and upstream. The basis of the LCA study is all the inventory input and output of industrial processes during the product life cycle which includes the production phase and process life cycle including the distribution, use and final disposal of products in each phase, in order to assess the impact.

The data required is collected at every stage, consisting of raw materials and quantity. The data is then processed using software SimaPro 9.0.0.29. The resulting impact encompasses (1) human health by DALY units (Disability Adjustment Life Years), (2) Ecosystem quality by $\mathrm{PDF}^{*} \mathrm{~m} 2 \mathrm{yr}$ (Potentially Disappeared Fraction of species per square meter per year), and (3) Resources Surplus with MJ (Mega Joule)[11].

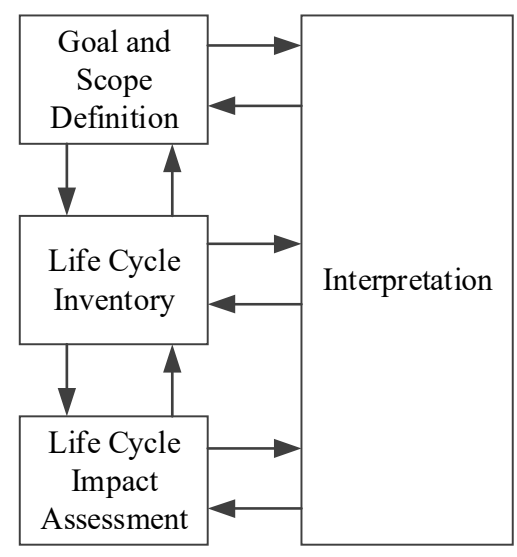

Fig. 1. Phase LCA 


\section{Results and Discussion}

This study analyzes the environmental impacts in every process of batik production, characterized by varying raw material and quantities. Table 1 presents information on the stages of the process and the raw materials required.

Table 1. Batik Production Processes and Raw Materials

\begin{tabular}{|c|c|c|}
\hline Process & Information & Raw Materials \\
\hline Coloring 1 & $\begin{array}{l}\text { Coloring process } 1 \text { is the first process to } \\
\text { provide basic pigmentation clothes. }\end{array}$ & $\begin{array}{l}\text { Mori Cloth, Remasol, } \\
\text { Water, Water Glass, } \\
\text { Soda Ash }\end{array}$ \\
\hline Stamp & $\begin{array}{l}\text { Stamping process is the second process that } \\
\text { creates a pattern on fabric }\end{array}$ & Night / wax, Gas \\
\hline Removing dyes & $\begin{array}{l}\text { Removing dyes process is a third process, } \\
\text { the process used to eliminate the color } \\
\text { fastness on fabric that is not affected the } \\
\text { stamp / wax }\end{array}$ & $\begin{array}{l}\text { Chlorine, sir Water, } \\
\text { Water }\end{array}$ \\
\hline Washing 1 & $\begin{array}{l}\text { This involves cleaning cloths } 1 \text { off the } \\
\text { remaining dye after separation }\end{array}$ & Water \\
\hline Washing 2 & $\begin{array}{l}\text { The washing process } 2 \text { is a process of } \\
\text { cleaning cloths } 1 \text { of a dye remaining after } \\
\text { dyes separating }\end{array}$ & Water \\
\hline Coloring 2 & $\begin{array}{l}\text { This is a dyeing process to enhance the } \\
\text { clothes looked attractiveness }\end{array}$ & $\begin{array}{l}\text { Remasol, Soda Ash, } \\
\text { Water Glass, Water }\end{array}$ \\
\hline Wax separating & $\begin{array}{l}\text { This is the last process with the function of } \\
\text { wax elimination }\end{array}$ & Firewood, Water \\
\hline
\end{tabular}

Table 1 describes the stages of the batik production process, as well as the raw materials used, and it is established that most are chemical in nature, with potential environmental impacts. Subsequently, the final waste materials from the batik production process are discharged directly into the river, without first undergoing treatment.

The type and quantity of raw material required for each stage production are shown in Table 2. These are usually procured monthly, due to the small scale of SMEs, with sub-optimal production compared to others, resulting from the limitations in capital and other resources. Therefore, the data needs are processed with SimaPro software, in order to determine possible environmental impacts.

Table 3 and Figure 2 show the criteria for environmental impact, which arises from each production stage. These are known to vary alongside the nature of materials used for the specific process. Hence, the damage criteria consist of three categories, including Human Health, Ecosystem Quality and Resources, which is calculated based on the selected raw material.

For example, damage category of coloring Process 1, Human health of 0.000237465 DALY, which means 0,000237465 years of healthy life lost numbers from an individual, in the form of possibly caused disabilities. 
Table 2. The Quantity of raw materials

\begin{tabular}{|c|c|c|}
\hline Process & Material & Quantity \\
\hline \multirow[t]{6}{*}{ Coloring 1} & Mori & $4 \mathrm{~kg}$ \\
\hline & Remasol & $1.2 \mathrm{~kg}$ \\
\hline & Water & 24 litre \\
\hline & Water Glass & $20 \mathrm{~kg}$ \\
\hline & soda ash & $2 \mathrm{~kg}$ \\
\hline & Water & 400 litre \\
\hline \multirow[t]{2}{*}{ Stamping } & Night & $8 \mathrm{~kg}$ \\
\hline & Gas & $12 \mathrm{~kg}$ \\
\hline \multirow[t]{2}{*}{ Removing Dyes } & chlorine & $20 \mathrm{~kg}$ \\
\hline & Water & 80 litre \\
\hline Washing 1 & Water & 400 litre \\
\hline Washing 2 & Water & 400 litre \\
\hline \multirow[t]{5}{*}{ Coloring 2} & Remasol & $1.2 \mathrm{~kg}$ \\
\hline & Water & 24 litre \\
\hline & Water Glass & $20 \mathrm{~kg}$ \\
\hline & soda ash & $2 \mathrm{~kg}$ \\
\hline & Water & 400 litre \\
\hline \multirow[t]{2}{*}{ Wax separating } & Water & 56.6 litre \\
\hline & gas & $1.2 \mathrm{~kg}$ \\
\hline
\end{tabular}

Table 3. Environmental impact

\begin{tabular}{cccc}
\hline Process & $\begin{array}{c}\text { Human Health } \\
(\mathrm{DALY})\end{array}$ & $\begin{array}{c}\text { Quality Ecosystem } \\
(\text { PDF } * \text { m2yr) }\end{array}$ & $\begin{array}{c}\text { Resources } \\
(\text { MJ surplus })\end{array}$ \\
\cline { 3 - 5 } Coloring 1 & 0.000237465 & 166.79561 & 80.803522 \\
Stamping & $5,50 \mathrm{E}-05$ & 2.6687806 & 152.64625 \\
Removing Dyes & 0.00014445 & 5.7365004 & 44.702271 \\
Washing 1 & $2,43 \mathrm{E}-07$ & 0.005514522 & 0.08622753 \\
Washing 2 & $2,43 \mathrm{E}-07$ & 0.005514522 & 0.08622753 \\
Coloring 2 & $8,17 \mathrm{E}-05$ & 11.193596 & 4.3560089 \\
Wax separating & $4,04 \mathrm{E}-06$ & 0.20809044 & 9.1583701 \\
Total & 0.000523106 & 179.77602 & 298.67646 \\
\hline
\end{tabular}

The quality of the ecosystem (Ecosystem Quality) is the caused by 166.79561 PDF * m2yr indicating the destruction of species ecosystem covering an area of $166.79561 \mathrm{~m} 2$ in one year. Resources (80) of $80.803522 \mathrm{MJ}$ surplus denotes the amount of basic energy needed to extract a natural resource of $80.803522 \mathrm{MJ}$ surplus. 


\section{Damage Category}

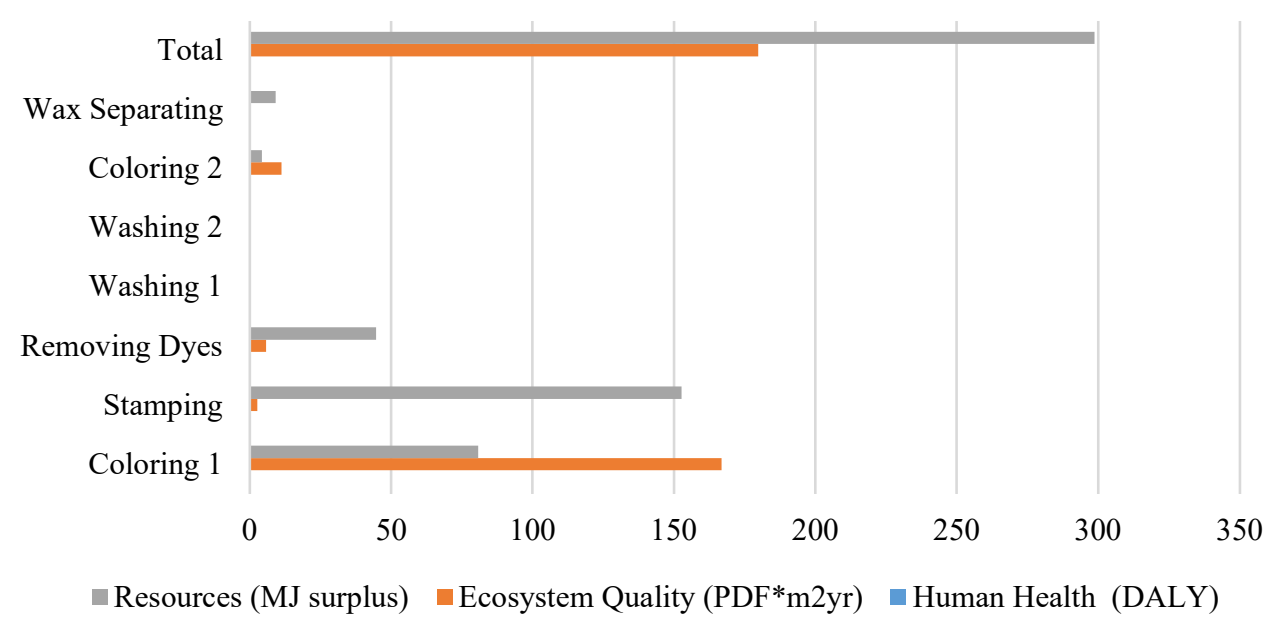

Fig. 2. Damage Category

Coloring process 1 results in the highest environmental impact, comparison with other processes. This is the first step required to provide basic pigmentation on clothes, and is known to require the use of water and chemical dyes as the main raw material. In addition, mori clothes, remasol, water, water glass and soda ash are also used, these materials are synthetic dyes that contain harmful chemicals. Furthermore, this step resulted in a higher environmental impact, compared with coloring 2 , as the differences between both stages was based on the raw materials used.

The results showed different environmental impacts at each stage of the batik production, depending on the material used. This was in line with the report of a previous study, which explained the total impact of the entire process, although reports on the proportional contribution of each stage are not available. In addition, the effect is possibly reduced through the efficient use of raw materials [9], as a research conducted by Rashidi explained the negative influence of wastefulness on the environment [7]. This study, therefore, complements previous research. by focusing on the reduction of materials used, while the discussion provides more details regarding the impacts reviewed from each stage.

There is a need to recommend solutions aimed at reducing the use of raw materials with high environmental impact in the production phase. Also, the recycle of raw materials, including wax, water and dye have proven to be beneficial, which leads to cost savings. These actions are expected to ensure good consistent production, subsequently reducing possible negative effects, resource consumption, and cost.

\section{Conclusion}

From the impact and damage analysis conducted, it can be seen that the coloring process 1 was confirmed to have the most significant environmental impact, both in aspect of ecosystem quality and resources. This process uses materials such as mori clothes, remasol, water, soda 
ash and water glass, which is difference from the materials used in coloring 2 for cloth. Recommendations for improvement are attainable by reducing the use of chemicals-based raw materials.

\section{References}

[1] V. Nindita and L. Belakang, "Perancangan dan aplikasi eko-efisiensi pada ukm batik nadia royani pekalongan," J. Ilm. Teknosains, vol. 3, no. 2, pp. 2-7, 2017. http://journal.upgris.ac.id/index.php/JITEK/article/view/1888/1510

[2] D. Hariani and D. Pratama, "Study of Creative Industry Development Based on Pekalongan Batik Culture," in WESTECH 2018, December 08, Medan, Indonesia, 2019. https://eudl.eu/doi/10.4108/eai.8-12-2018.2283854

[3] E. Muslimah and R. Rusdjijati, "Identifikasi Permasalahan Pengelolaan Limbah UKM Batik di Kota Magelang," in Industrial Engineering Conference, 2018, pp. 618-624. https://publikasiilmiah.ums.ac.id/handle/11617/9835?show=full

[4] S. Brammer, S. Hoejmose, and K. Marchant, "Environmental Management in SMEs in the UK: Practices, Pressures and Perceived Benefits," Bus. Strateg. Environ., vol. 21, no. 7, pp. 423-434, 2012. https://onlinelibrary.wiley.com/doi/abs/10.1002/bse.717

[5] E. Cagno and A. Trianni, "Evaluating the barriers to specific industrial energy efficiency measures: An exploratory study in small and medium-sized enterprises," J. Clean. Prod., vol. 82, no. November, $\quad$ pp. 70-83, 2014. https://www.sciencedirect.com/science/article/pii/S0959652614006453?via\%3Dihub

[6] S. Williams and A. Schaefer, "Small and Medium-Sized Enterprises and Sustainability: Managers' Values and Engagement with Environmental and Climate Change Issues," Bus. Strateg. Environ., vol. 22, no. 3, pp. 173-186, 2013. https://onlinelibrary.wiley.com/doi/abs/10.1002/bse.1740

[7] H. Rashidi, N. Meriam, N. Sulaiman, and N. A. Hashim, "Batik Industry Synthetic Wastewater Treatment Using Nanofiltration Membrane," in Procedia Engineering Euromembrane Conference, 2012, no. December, pp. 2010-2012. https://cyberleninka.org/article/n/946848

[8] M. L. Saqqo, "Analisis Produktivitas Pada Industri Batik Dengan Konsep Green Productivity ( Studi Kasus : Batik Putra Laweyan, Surakarta ) Dengan Konsep Green Productivity ( Studi Kasus : Batik Putra Laweyan , Surakarta )," Universitas Muhammadiyah Surakarta, 2017. http://eprints.ums.ac.id/53500/.

[9] N. D. Widodo, "Bentuk Penerapan Eko-Efisiensi pada Rantai Nilai di Klaster Batik Laweyan , $\begin{array}{lllll}\text { Kota Surakarta,” } & \text { vol. } & \text { 1, 287-302, }\end{array}$ https://ejournal2.undip.ac.id/index.php/jwl/article/view/142

[10] N. Indrasti and A. Fauzi, Produksi Bersih, 1st ed. Bogor: IPB Press, 2009.

[11] M. Peruzzini, M. Germani, and E. Marilungo, "Product-service sustainability assessment in Virtual Manufacturing Enterprises," IFIP Adv. Inf. Commun. Technol., vol. 408, pp. 13-21, 2013. https://link.springer.com/chapter/10.1007/978-3-642-40543-3_2 